\title{
KERJASAMA KEAMANAN AMERIKA SERIKAT-MEKSIKO (KASUS WEAK STATE DAN MERIDA INITIATIVE)
}

\author{
Luerdi \\ Mahasiswa Pascasarjana Ilmu Politik Universitas Riau
}

\section{Citation as}

Luerdi, L. (2014). Kerjasama Keamanan Amerika Serikat-Meksiko (Kasus Weak State dan Merida Initiative). https://doi.org/10.31219/osf.io/jfpw8 


\section{KERJASAMA KEAMANAN AMERIKA SERIKAT-MEKSIKO}

(Kasus Weak State dan Merida Initiative) ${ }^{1}$

\section{Luerdi}

\section{Mahasiswa Pascasarjana Ilmu Politik Universitas Riau}

\section{Pendahuluan}

Meksiko merupakan negara Amerika Latin yang berada di kawasan Amerika Utara dan tergabung dalam (North America Free Trade Agreement) NAFTA bersama Amerika Serikat dan Kanada. Dibandingkan dengan dua negara Amerika Utara lainnya, Meksiko masih tergolong sebagai negara berkembang dan memiliki jurang kesenjangan yang sangat kontras dengan kedua negara tersebut khususnya dalam hal kemajuan ekonomi dan kesejahteraan rakyatnya.

Selain itu, Meksiko menghadapi permasalahan domestik serius lainnya seperti tingkat korupsi yang tinggi, majemen pemerintahan yang buruk, lemahnya institusi dan penegakan hukum serta tingginya tingkat kekerasan akibat aktifitas kartel narkotika. Pemerintah Meksiko sering kewalahan menghadapi permasalahan-permasalahan domestik semacam ini. Sejak era pemerintahan Presiden Felipe Calderon sampai Presiden Pena Nieto kini, berbagai reformasi telah dilakukan khususnya dalam bidang hukum dan keamanan. ${ }^{2}$

Bagi Amerika Serikat, Meksiko merupakan mitra perdagangan penting dalam NAFTA. Meksiko menjadi salah satu tujuan ekspor dan investasi Amerika Serikat yang memberikan keuntungan bagi perekonomiannya. ${ }^{3}$

\footnotetext{
${ }^{1}$ Bahan diskusi perkuliahan pada Program Studi Ilmu Politik Pascasarjana Universitas Riau (2013-2014).

${ }^{2}$ Clare Ribando Seelke., at.al., U.S.-Mexican Security Cooperation: The Mérida Initiative and Beyond, Congressional Research Service, 08 April 2014, USA, Summary page.

3 U.S. Relations With Mexico., <http://www.state.gov/r/pa/ei/bgn/35749.htm>, [diakses 01 Desember 2014].
} 
Namun NAFTA tidak hanya memberikan dampak positif bagi Amerika Serikat tapi juga membuka ruang tumbuhnya ancaman domestik bagi negara tersebut yang datang dari luar. Meksiko sering menjadi perdebatan dalam politik domestik Amerika Serikat dan dianggap sebagai weak state yang dapat menjadi ancaman bagi keamanan dalam negerinya.

Selain tingginya jumlah immigran illegal Meksiko yang masuk ke Amerika Serikat, ketidakmampuan pemerintah Meksiko menangani kartel narkotika menjadi perhatian serius bagi Amerika Serikat. Amerika Serikat merupakan tujuan utama penyebaran obat-obatan terlarang dari Meksiko yang masuk melalui kegiatan penyelundupan di sepanjang garis perbatasan kedua negara. Produksi obat-obatan terlarang yang tinggi dalam negeri Meksiko tidak lepas dari tingginya tingkat permintaan yang datang dari dalam negeri Amerika Serikat.

Dalam merespon masalah aktifitas kartel narkotika dalam negeri Meksiko dan penyebaran obat-obatan terlarang ke Amerika Serikat, kedua negara telah menyepakati kerjasama keamanan yang dikenal dengan Merida Initiative. Merida Initiative mulai ditandatangani pada tahun 2007 di bawah pemerintahan Presiden Bush dan Presiden Calderon, dan mulai berlaku secara efektif pada tahun 2008. Dalam perjalanannya, kerjasama ini dinilai tidak memberikan hasil seperti yang diharapkan dan telah mengalami pergeseran di bawah pemerintahan Obama. Kerjasama Merida Initiative tetap dilanjutkan oleh kedua negara tapi dengan pendekatan yang berbeda yang dikenal dengan Beyond Merida; istilah yang digunakan oleh Presiden Obama. ${ }^{4}$

\section{Meksiko sebagai Weak State dalam Persepsi Amerika Serikat}

Dalam perkembangan isu keamanan dalam hubungan internasional antar negara, ancaman tidak lagi hanya berasal dari serangan suatu negara

\footnotetext{
${ }^{4}$ Sabrina Abu-Hamdeh., 'The Merida Initiative: An Effective Way of Reducing Violence in Mexico?', dalam Pepperdine Policy Review, Spring 2011, hal. 45.
} 
terhadap negara lain yang berdaulat. Negara-negara lemah (weak states) bahkan dapat menjadi ancaman yang serius bagi negara lain khususnya negara yang berdekatan secara geografis dengan negara-negara lemah tersebut. Weak state biasanya dapat dilihat dengan adanya capasity gaps yang diartikan sebagai kekosongan negara dalam berbagai fungsi dan peran yang kemudian mengakibatkan adanya functional hole. ${ }^{5}$

Functional holes yaitu kegagalan negara untuk mengisi fungsi-fungsi mendasar sebagaimana layaknya sebuah negara normal dan diharapkan oleh rakyatnya. ${ }^{6}$ Kegagalan suatu negara untuk menjalankan berbagai fungsinya baik dalam aspek ekonomi, politik, dan keamanan akan mendorong tumbuhnya berbagai kelompok kejahatan terorganisir yang tidak hanya beroperasi di dalam negara tersebut tapi juga transnasional. Ketidakmampuan negara untuk melakukan penegakan hukum terhadap kelompok-kelompok kejahatan tersebut berpeluang menciptakan instabilitas domestik. Sering kali masalah domestik weak state menembus teritorial negara lain sehingga menyebabkan kekhawatiran negara tersebut.

Bagi Amerika Serikat, Meksiko merupakan sebuah negara lemah (weak state) khususnya dalam hal penanganan kejahatan obat-obatan terlarang. Kelemahan Meksiko dalam mengatasi masalah ini berimbas pada konstelasi politik dan keamanan domestik Amerika Serikat karena negara tersebut adalah pasar utama produksi obat-obatan terlarang dari Meksiko. Amerika Serikat tidak membiarkan Meksiko sendirian mengatasi masalah ini karena Meksiko tidak akan mampu menghadapi masalahnya dengan berbagai keterbatasan yang ada. Sebaliknya membiarkan Meksiko sibuk dengan masalah domestiknya sendiri hanya akan memberikan dampak yang lebih buruk bagi Amerika Serikat. Kendati Meksiko dianggap sebagai weak state,

\footnotetext{
${ }^{5}$ Ratih Herningtyas., 'Weak State Sebagai Sebuah Ancaman Keamanan', dalam Jurnal Hubungan Internasional, Vol.5, No.1, April 2012, Jurusan Ilmu Hubungan Internasional Universitas Muhammadyah Yogyakarta, hal. 25.

${ }^{6}$ ibid.,
} 
Amerika Serikat menyadari bahwa Meksiko memiliki potensi bagi kepentingan ekonomi negara tersebut sehingga kerjasama keamanan menjadi pilihan yang lebih baik bagi kedua negara.7

\section{Kepentingan Amerika Serikat dan Meksiko}

Baik Amerika Serikat dan Meksiko sama-sama memiliki kepentingan dalam kerjasama keamanan yang dilakukan. Bagi Amerika Serikat, Meksiko yang lemah dengan berbagai permasalahan domestik dapat menjadi ancaman tidak langsung bagi stabilitas atau keamanannya. Ketidakmampuan pemerintah Meksiko menghentikan atau setidaknya mengontrol produksi obat-obatan terlarang oleh kartel narkotika akan semakin meningkatkan penyebaran obat-obatan tersebut ke Amerika Serikat, selain karena didukung oleh faktor geografis kedua negara yang berdekatan juga didukung oleh lemahnya penegakan hukum dan rendahnya kapasitas penegak hukum termasuk militer Meksiko dalam mengatasi masalah tersebut.

Tindak kekerasan antar katel narkotika sering terjadi di Meksiko bahkan di tempat-tempat umum yang meyebabkan korban jiwa dari rakyat sipil. Konflik yang terjadi antar kartel tersebut dapat menyebabkan gangguan terhadap stabilitas keamanan domestik Meksiko khususnya wilayah-wilayah yang berdekatan dengan Amerika Serikat. Bahkan kartel narkotika Meksiko dapat dengan mudah keluar-masuk Amerika Serikat. Instabilitas domestik Meksiko dapat pula mengganggu stabilitas domestik Amerika Serikat bila aktifitas kartel narkotika tersebut semakin tidak terkendali. ${ }^{8}$

Pemerintah Amerika Serikat berkepentingan untuk membantu pemerintah Meksiko dalam mewujudkan keamanan domestiknya dari aktifitas-

\footnotetext{
7 The US and Mexico - a strong but difficult relationship., <http://www.euronews.com/2014/02/18/the-us-and-mexico-a-strong-but-difficultrelationship/>, [diakses 01 Desember 2014].

${ }^{8}$ Putu Titah Kawitri Resen, et.al., 'Peran Amerika Serikat Dalam Kerjasama Penanggulangan Perdagangan Narkotika di Meksiko 2007-2012', dalam Jurnal Hubungan Internasional, FISIP Universitas Udayana, hal. 01.
} 
aktifitas kartel narkotika. Stabilitas Meksiko juga akan membantu menciptakan dan menjaga satabilitas domestik Amerika Serikat secara tidak langsung. Penegakan hukum terhadap kartel-kartel tersebut diharapkan mampu menghentikan atau mengurangi pasokan obat-obatan terlarang ke Amerika Serikat. Selain itu, stabilitas dalam negeri Meksiko akan mendorong optimalisasi kerjasama ekonomi dan investasi serta melindungi warga negara Amerika Serikat yang berada di Meksiko.

Bagi Meksiko, kerjasama keamanan dengan Amerika Serikat membuka pintu masuknya berbagai bantuan dari negara tersebut mulai dari bantuan finansial, pelatihan bagi para penegak hukum dan tentara, peralatan dan persenjataan, serta berbagai bantuan teknis lainnya. ${ }^{9}$ Pemerintah Meksiko menyadari berbagai kelemahan dan kendala yang dihadapi di dalam negeri walau berbagai reformasi telah digulirkan sehingga membutuhkan bantuan dari Amerika Serikat. Upaya pemerintah Meksiko menciptakan good governance diyakini tidak dapat dipisahkan dengan upaya menciptakan keamanan domestik yang kemudian dapat berkontribusi pada peningkatan kualitas kehidupan dan ekonomi rakyat Meksiko.

\section{Merida Initiative dan Pergeseran Pendekatannya}

Merida Initiative merupakan kerjasama keamanan antara Amerika Serikat dan Meksiko terkait dengan kekerasan akibat aktifitas kartel narkotika dan produksi obat-obatan terlarang dengan mengedepankan hak asasi manusia dan penegakan hukum. ${ }^{10}$ Selain dengan Meksiko, Amerika Serikat juga menjalin kerjasama Merida Initiative dengan negara-negara Amerika tengah. Dalam kasus Merida Initiative antara Amerika Serikat dengan Meksiko, kerjasama keamanan ini bertujuan untuk mengurangi tingkat kekerasan akibat

\footnotetext{
${ }^{9}$ Ray Walser., 'Mexico, Drug Cartels, and the Merida Initiative: A Fight We Cannot Afford to Lose', dalam Executive Summary Backgrounder, No.2163, July 2008, Washington, The Heritage Foundation, hal. 2-3.

${ }^{10}$ Merida Initiative., <http://www.state.gov/j/inl/merida/>, [diakses 01 Desember 2014].
} 
aktifitas kartel narkotika di Meksiko dan mengurangi penyebaran obat-obatan terlarang dari Meksiko ke Amerika Serikat. ${ }^{11}$

Model kerjasama ini adalah pemberian bantuan finansial dan teknis untuk meningkatkan kapasitas aparat penegak hukum termasuk militer Meksiko dalam menghadapi kartel-kartel narkotika. Amerika Serikat juga melengkapi kerjasama ini dengan memberikan bantuan persenjataan, helikopter, dan peralatan teknis lainnya termasuk bantuan teknologi dan pembangunan infrasruktur untuk membatasi aktifitas kartel-kartel narkotika dan penyebaran obat-obatan terlarang.

Merida Inititive memilki empat pilar utama, yaitu: ${ }^{12}$

1. Melumpuhkan kapasitas kejahatan yang terorganisir untuk beroperasi. Pilar ini bertujuan untuk melumpuhkan kekuatan kelompok-kelompok kejahatan terorganisir di Meksiko secara sistematis dengan menangkap para pemimpin mereka, mengurangi pendapatan perdagangan obatobatan dan menghentikan tindak pencucian uang, dan menghentikan produksinya.

2. Menginstitusionalisasikan kapasitas penegakan hukum yang berkelanjutan. Pilar ini bertujuan untuk meningkatkan kapasitas institusi-institusi keamanan publik, perbatasan, dan hukum Meksiko demi menegakkan aturan hukum.

3. Menciptakan struktur perbatasan abad ke-21. Pilar ini bertujuan untuk mengfasilitasi perdagangan dan perpindahan orang secara sah dan di saat bersamaan menghentikan aliran obat-obatan, orang, senjata, dan uang yang tidak sah antar kedua negara.

4. Membangun komunitas yang kuat dan berdaya tahan. Pilar ini bertujuan untuk memperkuat komunitas-komunitas dengan

\footnotetext{
${ }^{11}$ Sabrina Abu-Hamdeh., op.cit, hal.42.

${ }^{12}$ The Merida Initiative - An Overview., <http://mexico.usembassy.gov/eng/ataglance/meridainitiative.html $>$, [diakses 01 Desember 2014].
} 
menciptakan budaya sadar hukum dan memotong daya tarik dan kekuatan kelompok-kelompok perdagangan obat-obatan terlarang.

Setelah beberapa tahun berjalan, kerjasama Merida Initiative antara Amerika Serikat dengan Meksiko tersebut tidak memberikan hasil seperti yang telah direncanakan. Tingkat produksi obat-obatan terlarang di Meksiko tidak mengalami penurunan walaupun aparat penegak hukum dan militer Meksiko telah menangkap beberapa pimpinan kartel narkotika, begitu pula dengan tingkat permintaan obat-obatan terlarang dari Amerika Serikat yang tetap tinggi. ${ }^{13}$ Dalam kerjasama ini, pemerintah Amerika Serikat lebih banyak menghabiskan dana untuk keperluan militer seperti pelatihan-pelatihan bagi para aparat kepolisian dan militer Meksiko dan bantuan-bantuan perlengkapan militer untuk mereka. Jumlah dana yang telah dihabiskan oleh pemerintah Amerika Serikat tidak sebanding dengan apa yang diperoleh dalam kerjasama keamanan tersebut.

Selain itu, tingkat kekerasan akibat aktifitas kartel narkotika tetap tinggi di Meksiko. Tingginya tingkat kekerasan antar kartel narkotika di Meksiko tidak dapat dilepaskan dengan penggunaan senjata illegal yang diperoleh dari Amerika Serikat. ${ }^{14}$ Tingginya permintaan senjata illegal oleh kartel narkotika Meksiko kepada penyelundup yang ada di Amerika Serikat yang sebelumnya tidak menjadi perhatian dalam kerjasama Merida Initiative menjadi menyebab sulitnya mengurangi tingkat kekerasan.

Di bawah pemerintahan Presiden Obama, Amerika Serikat mulai melihat kerjasama Merida Initiative dengan pendekatan baru yang lebih dikenal dengan Beyond Merida Approach pada tahun 2011. Pendekatan ini tidak hanya melihat kewajiban yang semestinya dipenuhi oleh Meksiko dalam mengurangi produksi obat-obatan terlarang, tapi juga peran pemerintah

\footnotetext{
${ }^{13}$ Sabrina Abu-Hamdeh., op.cit, hal.43

14 ibid, hal. 44.
} 
Amerika Serikat dalam mencegah atau mengurangi distribusi senjata illegal dari dalam negerinya kepada kelompok-kelompok kejahatan di Meksiko. Pendekatan ini lebih menekankan pada bentuk kerjasama bilateral yang integratif antara Amerika Serikat dengan Meksiko sebagai wujud komitmen tanggungjawab bersama (shared responsibility) kedua negara tersebut. ${ }^{15}$

Beyond Merida tetap bertumpu pada empat pilar Merida Initiative dengan beberapa pergeseran paradigma. Adapun empat pilar dari Beyond Merida adalah sebagai berikut: ${ }^{16}$

1. Melumpuhkan dan menghentikan organisasi-organisasi kriminal dengan melihat mereka sebagai korporasi dan melumpuhkan perdagangan persenjataan yang berasal dari dalam Amerika Serikat.

2. Menginstitusionalisasikan penegakan hukum dengan meningkatkan alokasi dana untuk pembangunan institusi-institusi Meksiko yang kuat.

3. Membangun batas abad ke-21 dengan cara mengganti pemahaman definisi batas dari sekedar penggambaran geografis (geographic delineation) yang sederhana menjadi aliran keamanan (security flows). Ini diikuti dengan pemindahan lokasi beacukai dan keamanan dari daerah perbatasan ke kota pusat. Daerah perbatasan difokuskan pada pencegahan masuknya aliran-aliran yang illegal dan berbahaya.

4. Membangun komunitas-komunitas yang kuat dan berdaya tahan melalui reformasi sosial dan ekonomi yang dapat dimulai dari penciptaan lapangan kerja.

Merida Initiative dengan pendekatan baru (Beyond Merida) ini dinilai lebih baik ketimbang Merida Initiative pada era pemerintahan sebelumnya. Melihat pengeluaran atau belanja sebelumnya pada Merida Initiative yang tidak menunjukkan efektifitas, Beyond Merida lebih fokus pada pembangunan

15 ibid., hal. 46

16 ibid., hal. 45 
institusi (institution building) dalam negeri Meksiko ketimbang belanja militer. Namun dengan pendekatan kerjasama ini, pemerintah Amerika Serikat tetap tidak memberikan perhatian pada tindakan pencegahan dan penindakan terhadap permintaan obat-obatan yang datang dari dalam negerinya. ${ }^{17}$ Pada kenyataannya, permintaan yang berasal dari Amerika Serikat tetap menjadi pendorong produksi obat-obatan terlarang di Meksiko.

Walau kerjasama keamanan antara Amerika Serikat dan Meksiko tersebut belum benar-benar sesuai seperti apa yang diharapkan, kedua negara nampaknya masih berkepentingan terhadap model kerjasama tersebut. Implementasi dan kendala-kendala yang dihadapi tetap menjadi evaluasi penting sebagai catatan untuk mempertimbangkan kelanjutan kerjasama tersebut di masa yang akan datang.

\section{Kesimpulan}

Negara lemah (weak state) telah menjadi bentuk ancaman baru bagi negara-negara di dunia saat ini. Permasalahan domestik yang terdapat dalam suatu weak state memungkinkan terjadinya spill over dampak buruk kepada negara-negara lain khususnya yang berdekatan secara geografis. Negara yang merasa mendapatkan ancaman dengan keberadaan weak state akan merespon dengan cara melakukan intervensi ataupun kerjasama.

Kerjasama keamanan antara Amerika Serikat dan Meksiko yang dikenal dengan Merida Initiative didorong oleh ketidakmampuan pemerintah Meksiko untuk mengatasi masalah kartel narkotika dan perdagangan obat-obatan terlarang yang berasal dari dalam wilayahnya. Meksiko membutuhkan bantuan Amerika Serikat, sedangkan Amerika Serikat juga sulit untuk berlepas diri dari masalah domestik Meksiko tersebut. Walau Merida Initiative dinilai tidak terlalu berhasil mengurangi kekerasan akibat aktifitas kartel narkotika di Meksiko dan perdagangan obat-obatan terlarang ke Amerika Serikat,

17 ibid., hal. 48. 
kerjasama ini telah mampu menjembatani dialog antara kedua negara yang pernah mengalami hubungan yang buruk masa lalu. Kerjasama ini dapat dinilai sebagai optimisme mewujudkan hubungan yang lebih baik antara kedua negara dan integrasi regional di kawasan Amerika Utara.

\section{Referensi:}

Clare Ribando Seelke., at.al., U.S.-Mexican Security Cooperation: The Mérida Initiative and Beyond, Congressional Research Service, 08 April 2014, USA.

U.S. Relations With Mexico., <http://www.state.gov/r/pa/ei/bgn/35749.htm>, [diakses 01 Desember 2014].

Sabrina Abu-Hamdeh., 'The Merida Initiative: An Effective Way of Reducing Violence in Mexico?', dalam Pepperdine Policy Review, Spring 2011.

Ratih Herningtyas., 'Weak State Sebagai Sebuah Ancaman Keamanan', dalam Jurnal Hubungan Internasional, Vol.5, No.1, April 2012, Jurusan Ilmu Hubungan Internasional Universitas Muhammadyah Yogyakarta.

The US and Mexico - a strong but difficult relationship., <http://www.euronews. com/2014/02/18/the-us-and-mexico-a-strong-but-difficult-relationship/>, [diakses 01 Desember 2014].

Putu Titah Kawitri Resen, et.al., ‘Peran Amerika Serikat Dalam Kerjasama Penanggulangan Perdagangan Narkotika di Meksiko 2007-2012', dalam Jurnal Hubungan Internasional, FISIP Universitas Udayana.

Ray Walser., 'Mexico, Drug Cartels, and the Merida Initiative: A Fight We Cannot Afford to Lose', dalam Executive Summary Backgrounder, No.2163, July 2008, Washington, The Heritage Foundation.

Merida Initiative., <http://www.state.gov/j/inl/merida/>, [diakses 01 Desember 2014]. 
The Merida Initiative - An Overview., <http://mexico.usembassy.gov/eng/ata glance/merida-initiative.html>, [diakses 01 Desember 2014]. 